\section{Metallic Oxides with the Structure of High-speed Steel Carbide}

OxIDES isomorphous with the high-speed steel carbide $\mathrm{Fe}_{3} \mathrm{~W}_{3} \mathrm{C}$ have been found to exist with the ideal composition $M e_{3} \mathrm{Ti}_{3} \mathrm{O}$, where $M e$ is one of the transition metals manganese, iron, cobalt, nickel or copper (but not vanadium, chromium or zinc).

'The best agreement between calculated and observed $p|F|^{2}$ values for powder photograph reflexions and the best space distribution in the cubic unit cell is obtained if the 112 atoms are placed in the following positions of the space group $\mathrm{O}_{h^{7}}-F d 3 m$ :

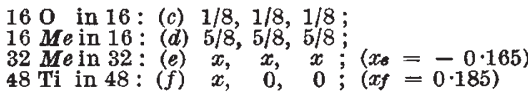

Analysis of powder photographs taken with oxides of different compositions gives the probable lower and upper phase limits for the titanium content as $M e_{3} \mathrm{Ti}_{3} \mathrm{O}$ and $M e_{2} \mathrm{Ti}_{4} \mathrm{O}$ respectively. At the latter composition 16 titanium atoms and $16 \mathrm{Me}$ atoms are randomly distributed in $32:(e)$. In comparison, 16 iron atoms take up the positions of 16 tungsten atoms in $48:(f)$ in high-speed steel carbide of the composition $\mathrm{Fe}_{4} \mathrm{~W}_{2} \mathrm{C}$. The following values for the length of the unit cube edge have been found:

$\begin{array}{ccc}M e & \text { Titanium-poor limit } & \text { Titanium-rich limit } \\ \text { Mn } & 11 \cdot 10 \mathrm{~A} & 11 \cdot 28 \mathrm{~A} . \\ \mathrm{Fe} & 11 \cdot 14 & 11 \cdot 31 \\ \mathrm{Co} & 11 \cdot 16 & 11 \cdot 32 \\ \mathrm{Ni} & 11 \cdot 18 & \mathbf{1 1} \cdot 37 \\ \mathrm{Cu} & \mathbf{1 1} \cdot \mathbf{2 4} & \mathbf{1 1} \cdot 44\end{array}$

All the new oxides have metallic properties. It is of interest that the titanium atoms, independent of the composition, are surrounded octahedrally by six oxygen atoms.

A detailed report will appear shortly elsewhere.

Institute of Chemistry,

NILS KARLSSON

University,

Uppsala.

May 23.

\section{Source of Moulting Hormone in Rhodnius}

THE immediate source of the hormone which induces moulting in the larvæ and pupæ of Lepidoptera is the prothoracic gland ${ }^{1}$. But this gland is itself activated by a secretion from neuro-secretory cells in the dorsum of the brain ${ }^{2}$. It has seemed probable for some time that a similar two-stage control of moulting might exist in other insects ${ }^{3}$; and recently it has been found by Possompès ${ }^{4}$ that the lateral cells of the ring gland in the larvæ of Diptera are induced to secrete the pupation hormone by a factor liberated from the brain.

It has now been shown that the same sequence of events occurs in Rhodnius. Fourth-stage larvæ of Rhodnius decapitated at $24 \mathrm{hr}$. after feeding can be induced to moult by implanting into the abdomen the dorsal region of the brain from larvæ that have just passed the 'critical period's. In the present series, this experiment succeeded in 80 per cent of cases. But if the recently fed larva is ligatured behind the mesothorax and the same implants are made into the isolated abdomen, this fails to moult. There were no positive results in twenty-three experiments.

Search in the thorax has revealed the presence of two strands of large cells, with enormous lobulated nuclei, deeply imbedded in the fat body and extending throughout the prothorax and mesothorax. These cells are abundantly supplied with tracheoles. They undergo a cycle of development in each moult, increasing greatly in size at the 'critical period', becoming small again at the end of the moulting stage. They break down and disappear in the adult within forty-eight hours after moulting.

If these cells are removed from a larva that has just passed the critical period and are implanted into the abdomen of a larva decapitated at $24 \mathrm{hr}$. after feeding, this is caused to moult (six positive in eighteen experiments). If they are implanted into recently fed larvæ ligatured through the metathorax, the isolated abdomen is likewise caused to moult (seven positive among thirteen survivors).

Similarly, the adult Rhodnius is not caused to moult by implantation of the brain; but moulting is induced if the thoracic gland from the moulting fifth-stage larva is implanted.

A corresponding gland has been found also in $N e p a$, where it likewise disappears in the adult insect.

$$
\text { V. B. WIGGLESWORTH }
$$

Department of Zoology,

University, Cambridge. July 28.

1 Fukuda, S., Proc. Imp. Acad, Tokyo, 18, 414 (1940).

${ }^{2}$ Williams, C. M., Biol. Bull., 93, 89 (1947).

${ }^{3}$ Wigglesworth, V. B., Bull. Biol. Franc. et Belg. Supp., 38, 174 (1947).

- Possompès, B., C.R. Acad. Sci., Paris, 231, 594 (1950).

${ }^{\circledR}$ Wigglesworth, V. B., J. Exp. Biol., 17, 201 (1940).

\section{Activation and the Correlation between Male and Female Elements in Fertilization}

IN the course of investigations on the process of fertilization, immature rats, which had been allowed to mate, were killed shortly after induced ovulation. Thirty-six animals yielded 477 eggs in the early phase of fertilization. The correlation in the stages shown by the male and female elements in the living eggs was carefully examined with the aid of the phasecontrast microscope. The stages were classified as follows : for the male element, $(a)$ sperm present in the perivitelline space, $(b)$ sperm in the vitellus but with head unchanged, (c) sperm head changing, (d) male pronucleus forming; for the female element, (a) chromosomes in metaphase of second maturation division, $(b)$ in anaphase, $(c)$ in telophase, $(d)$ polar body abstricted, $(e)$ female pronucleus forming. The numbers of eggs showing these stages are recorded in the accompanying table.

Of the 108 eggs which contained sperms only in the perivitelline space, the great majority (103) displayed chromosomes arranged in metaphase. In the

Correlation between Male and Frmale Giements duRing Early STAges of Fertilization IN 477 RAT EgGS

\begin{tabular}{|c|c|c|c|c|c|}
\hline Male Female & $\begin{array}{l}\text { Chromo- } \\
\text { somes } \\
\text { in meta- } \\
\text { phase }\end{array}$ & $\begin{array}{l}\text { Chromo- } \\
\text { somes } \\
\text { in ana- } \\
\text { phase }\end{array}$ & $\begin{array}{l}\text { Chromo- } \\
\text { somes } \\
\text { in telo- } \\
\text { phase }\end{array}$ & $\begin{array}{c}\text { Polar } \\
\text { body } \\
\text { formed }\end{array}$ & $\begin{array}{c}\text { Pro- } \\
\text { nucleus } \\
\text { forming }\end{array}$ \\
\hline $\begin{array}{l}\text { Sperm in peri- } \\
\text { vitelline space } \\
\text { Sperm in vitel- } \\
\text { lus, unchanged } \\
\text { Sperm in vitel- } \\
\text { lus, head } \\
\text { changing } \\
\text { Pronucleus } \\
\text { forming }\end{array}$ & $\begin{array}{r}103 \\
4\end{array}$ & $\begin{array}{l}1 \\
8\end{array}$ & $\begin{array}{l}1 \\
6\end{array}$ & $\begin{array}{r}173 \\
47\end{array}$ & $\begin{array}{r}1 \\
77\end{array}$ \\
\hline
\end{tabular}

